\title{
Perancangan Pembangunan Poskamling untuk Keamanan \& Pemantauan Covid 19 di Nologaten, Caturtunggal, Depok, Sleman
}

\author{
Anita Rahmawati*1, Emil Adly², Fayka Fidelia ${ }^{3}$ \\ 1,2,3Program Studi Teknik Sipil, Fakultas Teknik, Universitas Muhammadiyah Yogyakarta \\ *e-mail: anita.rahmawati@umy.ac.id ${ }^{1}$, emil@umy.ac.id², fayka.fidelia.ft17@mail.umy.ac.id ${ }^{3}$
}

\begin{abstract}
In order to face the challenges of increasingly complex security conditions and also to adapt to the new order of life during the Covid 19 pandemic, the management of RW 04 Dusun Nologaten intends to build Poskamling to support residents' security activities. This Poskamling will be used as a place to monitor access in and out of RW 04 Dusun Nologaten. The aim of this community service is to assist the Management of RW 04 Dusun Nologaten in realizing the development of poskamling in the form of technical consultation assistance before and during implementation. The method of implementing the activities carried out includes the process of designing the poskamling building structure and the assistance process during its construction. With the realization of the Poskamling development, it can be used for patrol activities, security guards more comfortably in the Nologaten area RW 04 Caturtunggal, Depok, Sleman.
\end{abstract}

Keywords: Design Drawing, Design, Poskamling.

\begin{abstract}
Abstrak
Dalam rangka menghadapi tantangan kondisi keamanan yang semakin kompleks dan juga untuk beradaptasi dengan kondisi di saat pandemi Covid 19, maka pengurus RW 04 Dusun Nologaten bermaksud untuk membangun Poskamling guna menunjang kegiatan keamanan warga. Poskamling ini akan digunakan sebagai tempat memantau akses keluar masuk ke RW 04 Dusun Nologaten. Tujuan Pengabdian ini untuk membantu Pengurus RW 04 Dusun Nologaten dalam mewujudkan pembangunan poskamling berupa bantuan konsultasi teknis sebelum dan selama pelaksanaan. Metode pelaksanaan kegiatan yang dilakukan meliputi proses perancangan struktur bangunan poskamling dan proses pendampingan selama pembangunanya. Dengan sudah terealisasinya pembangunan Poskamling ini maka bisa dimanfaatkan untuk kegiatan ronda, penjagaan kemanan dengan lebih nyaman di wilayah Nologaten RW 04 Caturtunggal, Depok, Sleman.
\end{abstract}

Kata kunci: Gambar Desain, Perancangan, Poskamling

\section{PENDAHULUAN}

Di penghujung tahun 2019, dunia dihebohkan dengan adanya virus corona baru bernama SARSCoV2. Pada Februari 2020, Organisasi Kesehatan Dunia (WHO) memutuskan COVID 19 yang merupakan singkatan dari Coronavirus Disease 2019 ini akan menyebar dengan sangat cepat. Pasien dengan COVID-19 biasanya memiliki gejala mulai dari tanpa gejala hingga pneumonia yang sangat parah. Sindrom gangguan pernapasan akut, syok septik, kegagalan multi organ, sindrom ini bisa berakibat fatal (Wei-jie Guan, et.al., 2020). Siskamling digerakkan kembali dalam rangka pencegahan penyebarang secara masih di lingkungan masyarakat seperti yang telah dicanangkan dalam PP Pasal 1, Nomor 21 Tahun 2020 tentang pengertian PSBB adalah Pembatasan Sosial Berskala Besar adalah pembatasan kegiatan tertentu penduduk dalam suatu wilayah yang diduga terinfeksi Covid-19 diupayakan supaya melakukan pencegahan kemungkinan penyebaran CovidI9 tersebut (Peraturan Pemeritah, 2020). (Pribadi, 2020) menjelaskan bahwa Poskamling yang merupakan sistem keamanan secara mandiri di lingkungan masyarakat bisa sebagai langkah antisipasi dalam penanaganan keamanan dan juga sebagai pencegahan penularan Covid 19 secara masif di lingkungan masyarakat. Peran aktif dan partisipasi masyarakat dalam kegiatan perancangan desa dapat memberikan hasil sesuai dengan kebutuhan (Prahati, dkk., 2017).

Menurut (Rukmana, 1993) mengatakan keterlibatan masyarakat telah membantu upaya untuk memanfaatkan dana yang terbatas dan masyarakat bisa langsung memantau semua kegiatan yang bersumber dari publik. Sistem keamanan lingkungan merupakan salah satu upaya untuk menjaga keamanan dan ketertiban desa dengan partisipasi dari seluruh warga. Sistem keamanan lingkungan merupakan bentuk kemandirian yang merupakan integrasi dari komponen yang 
saling bergantung dan saling terkait yang memberikan rasa aman dalam masyarakat dan mendukung tercapainya Pancasila dan masyarakat madani yang adil dan makmur berdasarkan Pancasila dan UUD 1945 (Husin,dkk., 2018). Selain itu, menurut (Fitriana, dkk., 2020) menyatakan bahwa pemberdayaan masyarakat dapat meningkatkan perekonomian desa. Dalam Rangka menghadapi kondisi pandemi yang semakin lama semakin menyebar pesat maka Masyarakat Dusun RW 04 Nologaten Catur tunggal Depok Sleman membutuhkan tempat untuk melakukan penjagaan dan pemantauan terutama terhadap keluar masuknya orang ke Dusun RW 04 Nologaten Catur tunggal Depok Sleman. Maka untuk itu pengurus RW 04 Dusun Nologaten bermaksud untuk membangun prasarana keamanan guna menunjang kegiatan menjaga keamanan warga dengan membangun Poskamling di wilayah RW 04 Nologaten, Caturtunggal, Depok, Sleman. Rencananya Poskamling ini akan digunakan sebagai tempat untuk memantau akses keluar masuk ke RW 04 Dusun Nologaten terutama di malam hari. Selama pandemi ini berlangsung akses keluar masuk di RW 04 Nologaten Caturtunggal Depok Sleman dipusatkan hanya satu pintu saja yang berada di Utara Makam Sasonoloyo, hal ini dilakukan untuk mengidentifikasi keluar masuknya orang dari luar daerah ke Dusun Nologaten RW 04 sehingga harapananya bisa menghindari penyebaran virus Covid 19 yang sekarang sedang mewabah. Perlunya Pembangunan Poskamling ini dikarenakan selama ini petugas penjaga pos pintu masuk ke Dusun Nologaten RW 04 hanya membuat bangunan sementara di sebelah Barat Makam dengan menggunakan seng dan terpal sebagai penutupnya dan sangat sempit sehingga tidak nyaman bagi petugas yang jaga. Hal ini juga diperkuat oleh pernyataan (Tjokromidjojo, 1990), bahwa kekuatan masyarakat sendiri yang meliputi manusia dan struktur sosial bisa menjadikan pembangunan lebih maju(self sustraining process).

Pos Penjagaan sementara saat ini berada di sisi barat dari Makam Sasonoloyo (seperti yang terlihat pada Gambar 1) di Dusun Nologaten RW 04 terletak di Dusun Nologaten, Kecamatan Depok, Kabupaten Sleman, Daerah Istimewa Yogyakarta. Berikut batas wilayah dari RW 04 Dusun Nologaten:

- sisi Utara : Dusun Pringwulung

- sisi Timur : Dusun Mundu Saren

- sisi Selatan : Dusun Gaten

- sisi Barat : Dusun Papringan
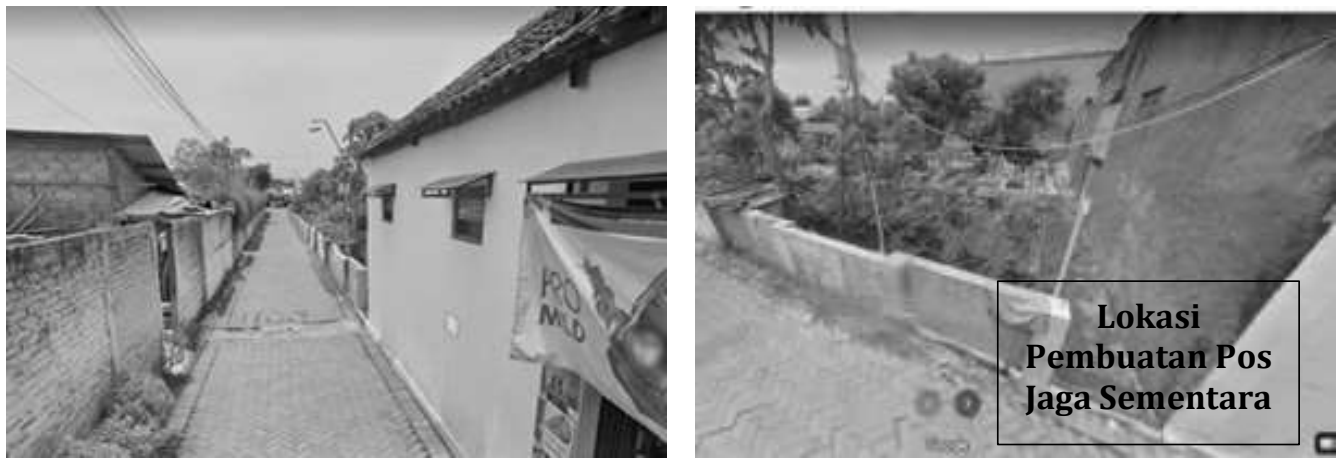

Gambar 1. Lokasi Pos Penjagaan Sementara

Menurut (Sudibyo, 2006), pembangunan partisipatif ini bertujuan untuk meningkatkan kesadaran masyarakat sekaligus menata kembali tatanan sosial yang melingkupinya. Realisasi ini membutuhkan keterlibatan langsung semua pihak yang terlibat dalam pengambilan keputusan dan implementasi yang berdampak langsung pada kehidupan mereka, tergantung pada kebutuhan yang mendasari lingkungan bersama. Pembangunan partisipatif ini merupakan model pembangunan yang melibatkan masyarakat sebagai penerima manfaat utama dan pelaku proaktif mengambil langkah-langkah penting yang diperlukan untuk meningkatkan taraf hidup masyarakat. Penyelesaian dari permasalahan diatas adalah perlunya Pembangunan Poskamling ini dikarenakan selama ini petugas penjaga pos pintu masuk ke Dusun Nologaten RW 04 hanya membuat bangunan sementara di sebelah Barat Makam dengan menggunakan seng sebagai 
putupnya dan sangat sempit sehingga tidak nyaman bagi petugas yang jaga. Sehingga harapannya dengan pembuatan Pos Kamling ini yang berlokasi dibarat makam, bisa menjadi tempat yang lebih nyaman bagi petugas yang berjaga di pintu masuk Dusun Nologaten RW 04. Pengabdian ini harapannya bisa membantu Pengurus RW 04 Dusun Nologaten dalam pembangunan Pos Kamling baik berupa bantuan konsultasi teknis selama pelaksanaan dan bantuan sebagian pendanaan guna pengadaan material konstruksi, dalam rangka mewujudkan pelaksanaan Pembangunan Pos Kamling.

\section{METODE}

Metode pelaksanaan kegiatan yang dilakukan meliputi proses perancangan struktur dan proses pendampingan selama pembangunan yang dilakukan. Adapun tahapan kegiatan pengabdian kepada masyarakat adalah sebagai berikut:

1. Pertemuan dengan Pengurus RW 04 untuk mendiskusikan perencanaan dan pelaksanaan pembangunan Poskamling di Dusun Nologaten RW 04 Caturtunggal Depok Sleman.

2. Tahap Survei lokasi, untuk mengetahui posisi dimana poskamling ini mau dibangun, survei dilakukan secara bersama-sama dengan masyarakat, hal ini dikarenakan pembangunan poskamling ini akan dilakukan secara gotong royong bersama semua warga masyarakat.

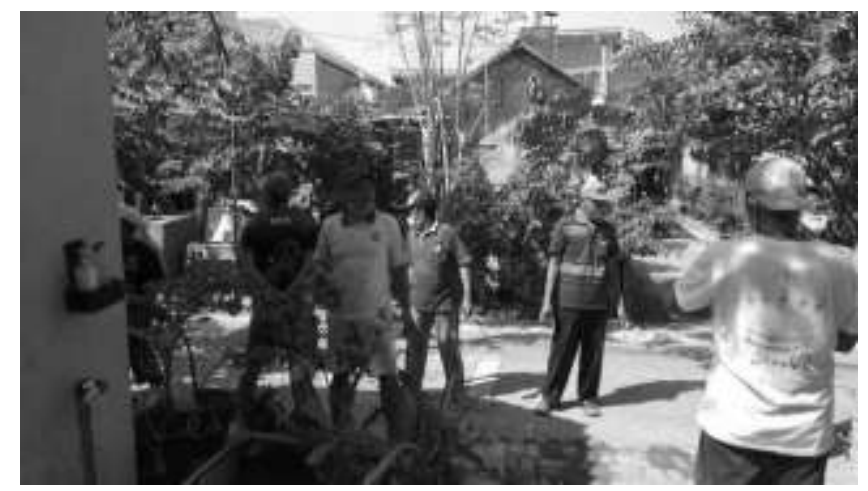

Gambar 2. Tahap survei lokasi akan di bangunnya poskamling

3. Tahap perencanaan yang berupa penggambaran struktur dan penghitungan biaya pembangunan sesuai dengan SNI 1727:2013 tentang beban minimum untuk perancangan bangunan gedung dan struktur lain (Standar Nasional Indonesia, 2013).

4. Tahap pelaksanaan, setelah tahap perancanagan selesai dan disepakati oleh semua pihak maka dilanjutkan ke tahap pelaksanaan. Disini biaya untuk mewujudkan rencana pembangunan poskamling tersebut diharapkan dari swadaya masyarakat dan para donator dari berbagai kalangan. Tahap pelaksanaan dapat dilihat pada Gambar 3 sampai Gambar 7.

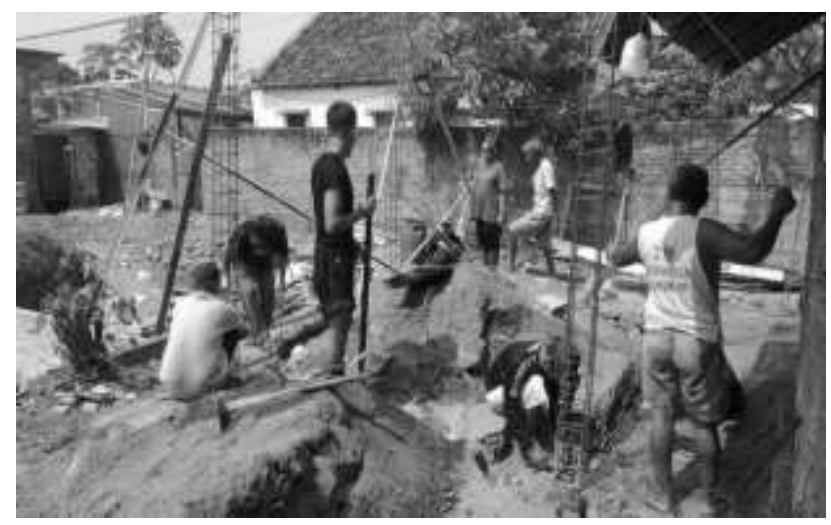

Gambar 3. Pemasangan Tulangan Sloof dan Tulangan Kolom 


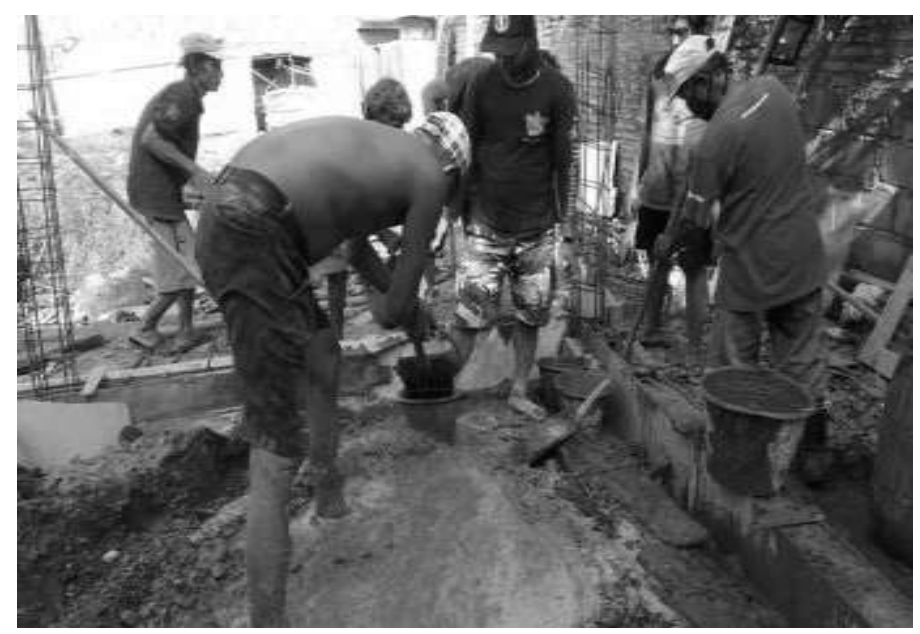

Gambar 4. Pengecoran Sloof

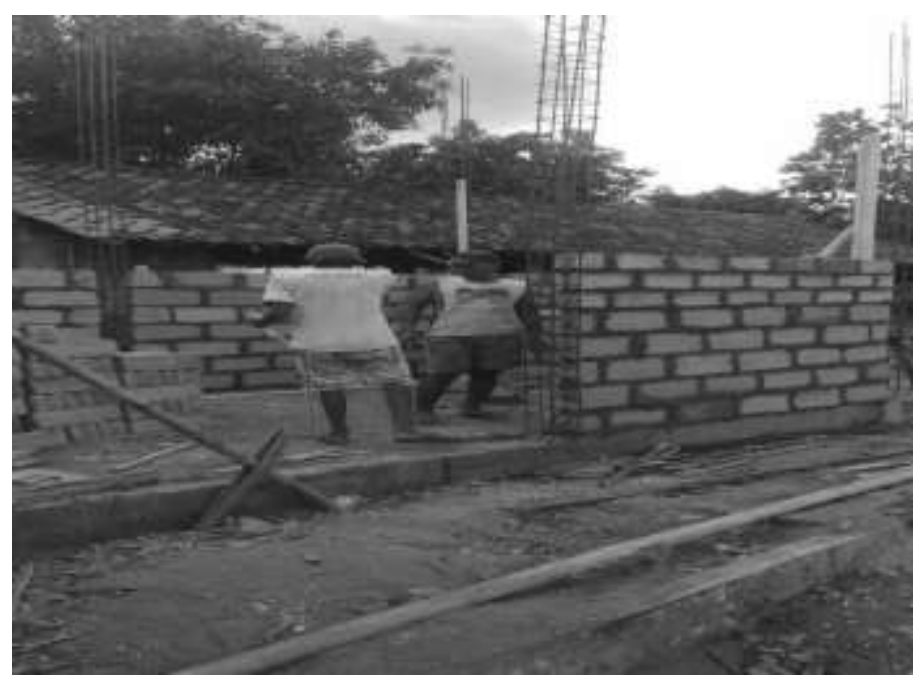

Gambar 5. Pemasangan Batako

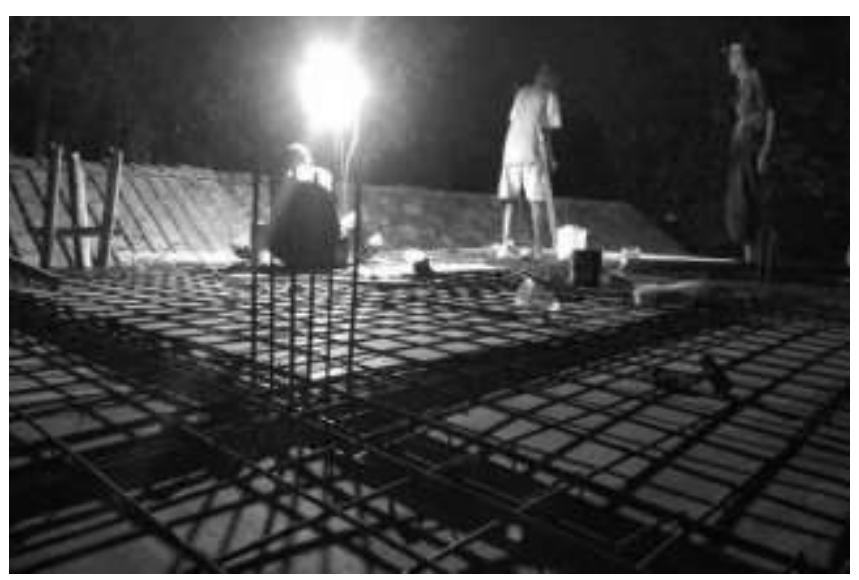

Gambar 6. Pemasangan Plat lantai atas 


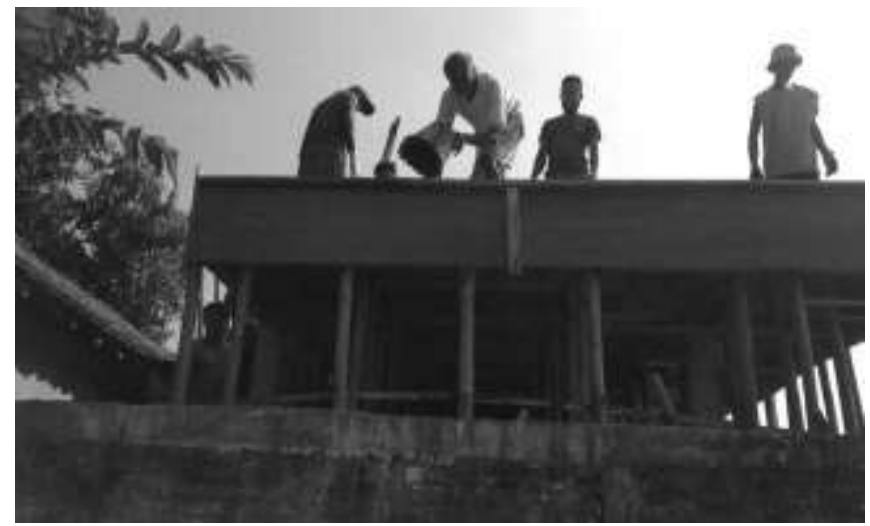

Gambar 7. Pengecoran Plat Lantai atas

Kegiatan pengabdian kepada masyarakat ini melibatkan 2 orang dosen dan 2 orang mahasiswa sebagai pengabdi, yang memberikan bantuan pendampingan selama proses pembangunan.

\section{HASIL DAN PEMBAHASAN}

3.1 Hasil Perancangan Struktur Bangunan Poskamling dengan Autocad

Hasil perancangan struktur bangungan poskamling dengan bantuan software autocad dapat dilihat pada Gambar 8 sampai Gambar 11.

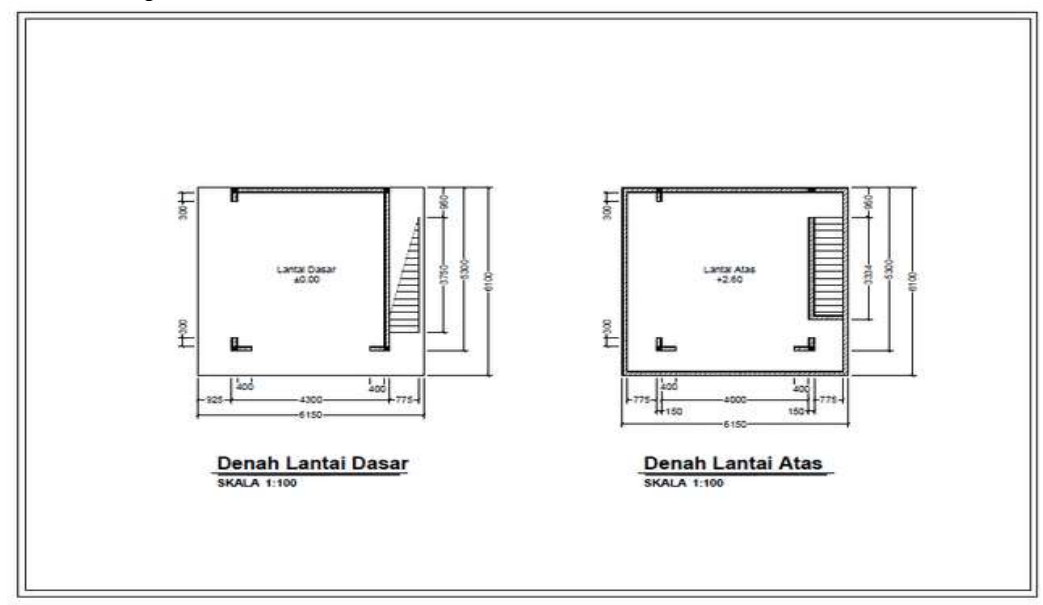

Gambar 8. Denah Lantai Dasar dan Lantai Atas

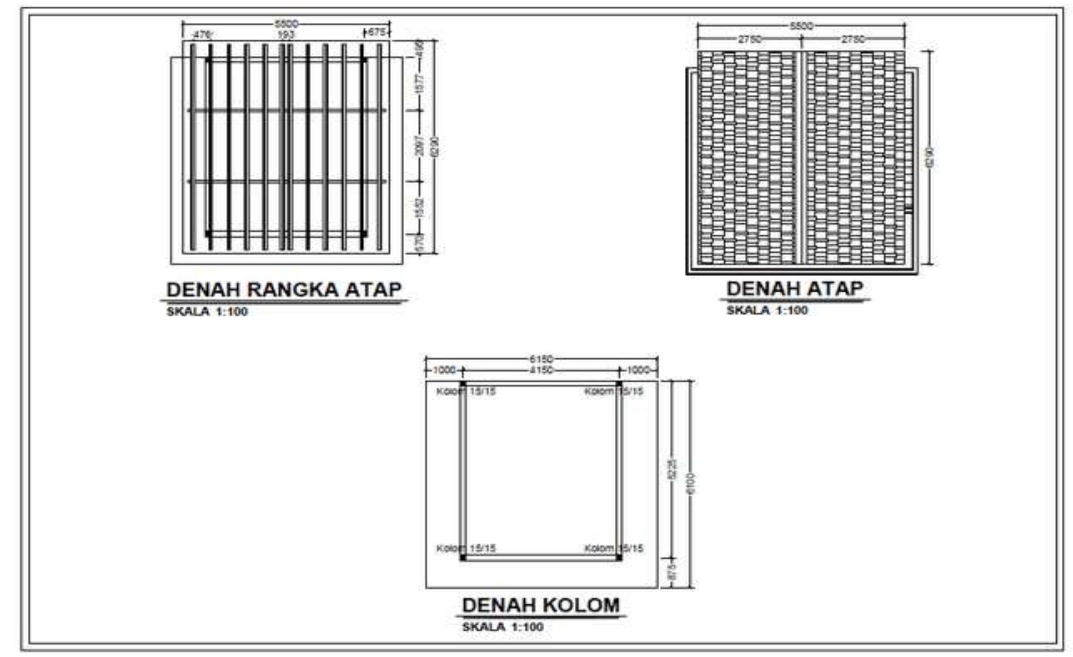

Gambar 9. Denah Atap dan Kolom 


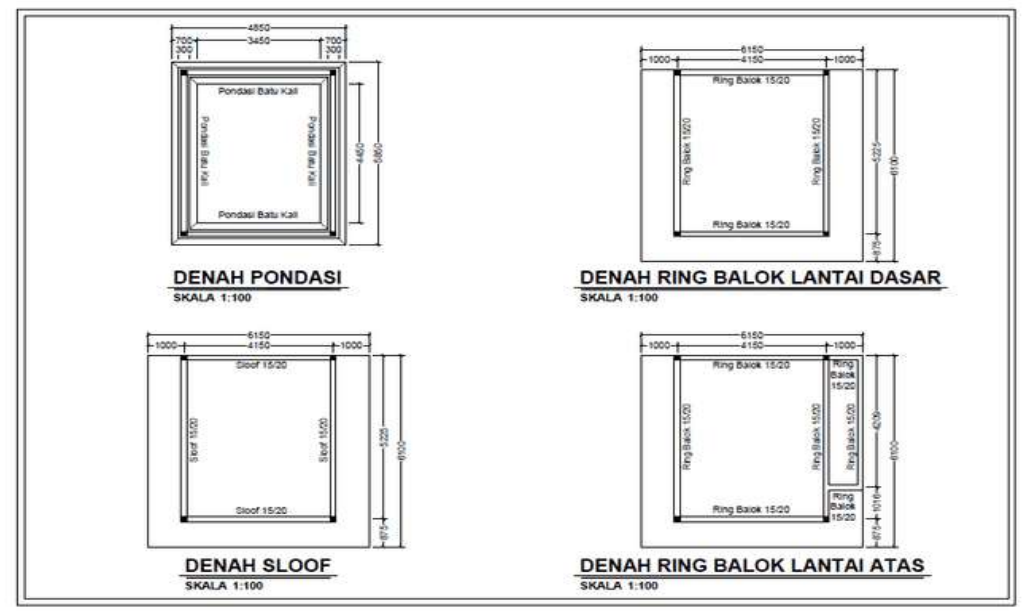

Gambar 10. Denah Pondasi, Sloof dan ring Balok

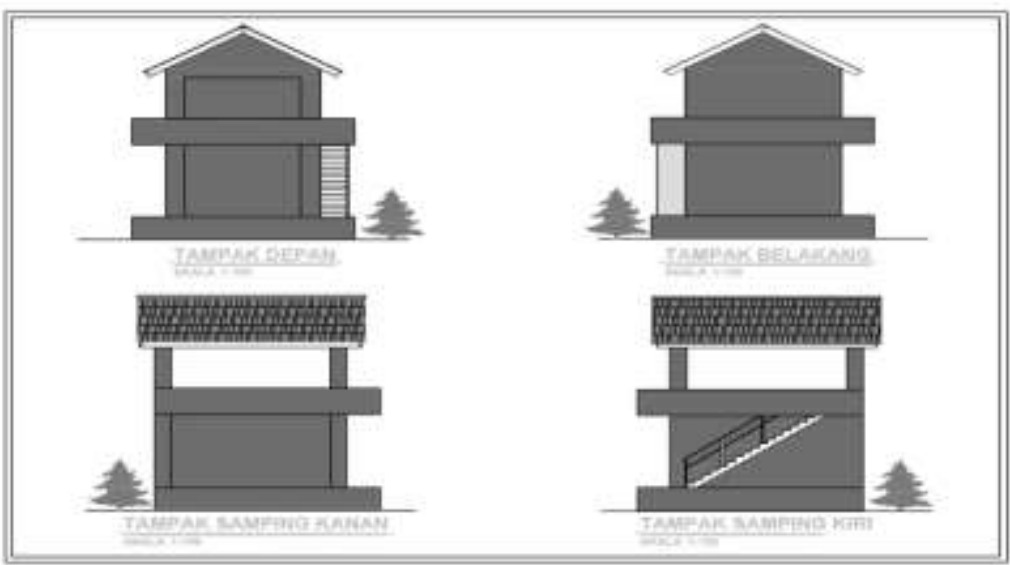

Gambar 11. Tampak Depan, Belakang dan Samping

\subsection{Hasil Pembangunan Bangunan Poskamling}

Hasil pelaksanaan pada pembangunan poskamling dapat dilihat pada Gambar 12 dan 13 dibawah ini. Pelakasanaan pembangunan belum selesai 100 persen, baru sampai ke cor lantai atas, hal ini dikarenakan terkendala dalam hal pendanaan. Dari hasil pembangunan yang sudah dilaksanakan secara gotong royong dengan cara kerja bakti ini, sesuai dengan penelitian yang sudah dilakukan oleh (Kalla, dkk., 2018), yang mengatakan bahwa pastisipasi masyarakat secara bergotong royong, kerja bakti, dsb., bisa mengatasi permasalahan yang ada di masyarakat.
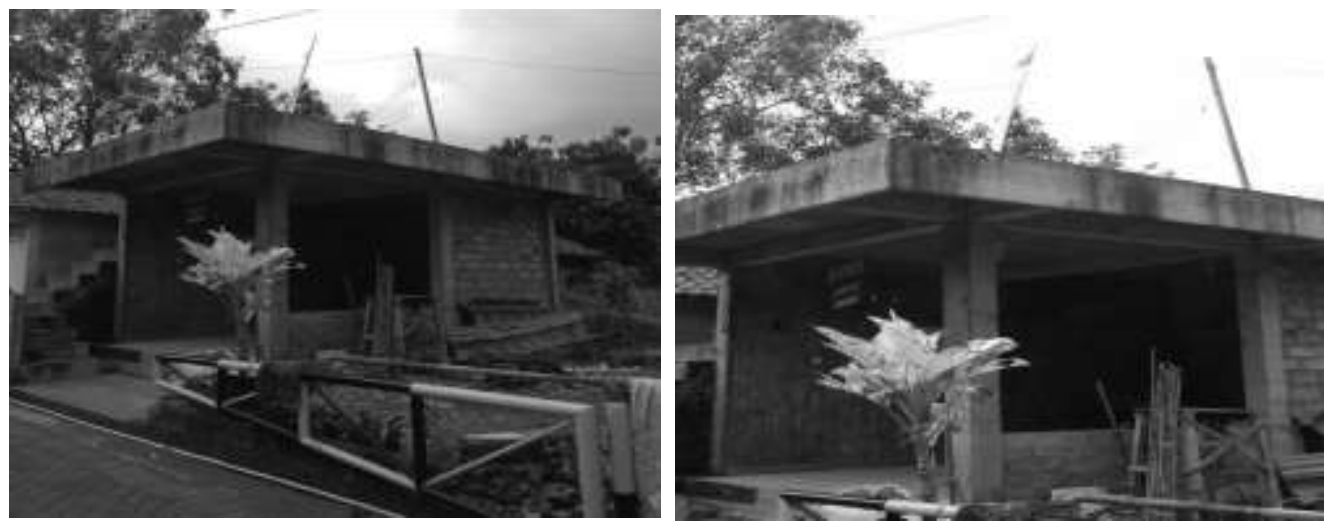

Gambar 12. Hasil Pembangunan Poskamling Tahap I (Lantai bawah) 


\section{KESIMPULAN}

Tim Pengabdian kepada Masyarakat (PkM) Program Studi Teknik Sipil Universitas Muhammadiyah Yogyakarta telah membantu proses perancangan dan proses pelaksanaan pembangunan pembangunan poskamling di Nologaten, Caturtunggal, Depok, Sleman, Daerah Istimewa Yogyakarta. Dari proses perancangan telah dihasilkan gambar desain bangunan poskamling. Dari proses pembangunan, Tim PkM memberikan bantuan pendampingan selama pelaksanaan. Dengan selesainya PKM pembangunan poskamling ini, maka diharapkan pelaksaan penjagaan kemaanan seperti ronda dan penjaagaan terkait akses keluar masuknya orang ke kampung Nologaten jadi lebih mudah dan nyaman

\section{UCAPAN TERIMA KASIH}

Ucapan terima kasih disampaikan kepada:

1. Lembaga Penelitian, Publikasi, dan Pengabdian Masyarakat Universitas Muhammadiyah Yogyakarta (LP3M UMY) yang telah memberikan kesempatan dan mendanai kegiatan pengabdian kepada masyarakat ini sehingga kegiatan berjalan dengan lancar.

2. Pengurus RW 04 Nologaten, Caturtunggal, Depok, Sleman atas kerjasama yang baik sehingga kegiatan pengabdian ini bisa terlaksana sesuai target.

\section{DAFTAR PUSTAKA}

Husin, B.A., Asnawi, R., Andrisman, T., (2018). Jurnal Poenale, 6 (3).

Rukmana, N. (1993). Manajemen Pembangunan Prasarana Perkotaan: PT Pustaka LP3S.

Badan Nasional Indonesia. (2013). SNI 1727:2013: Beban minimum untuk perancangan bangunan gedung dan struktur lain. Jakarta: BSN.

Fitriana, N., Yuniwati, E. D., \& Darmawan A., A., \& Firdaus, R. (2020). Eksplorasi Potensi Alami Waduk Menuju Rancangan Wisata Desa Purwosekar Tajinan Kabupaten Malang. Dinamisia, 4(3), 398-406.

Peraturan Pemerintah (2020). PP No 21 Tahun 2020 tentang Pembatasan Sosial Berskala Besar dalam Rangka Percepatan Penanganan Corona Virus Disease 2019 (COVID 19). Jakarta.

Prahati, Zuhdi, S., \& Aguswan. (2017). Penyuluhan Penyusunan Rencana Pembangunan Desa, di Desa Kuapan, Kecamatan Tambang, Kabupaten Kampar. Dinamisia, 1 (1), 94-99.

Pribadi, S. (2020). Revitalisasi Pos Kamling Berbasis Komunitas di Masa Pandemi Covid-19. Jurnal Keamanan Nasional 6 (2), 304-321.

Sudibyo, R. P. (2006). Partisipasi Masyarakat Sub Urban Dalam Pembangunan Kota Malang. Huminity, 1 (2), 76-86.

Tjokromidjojo, B. (1990). Strategi Pembangunan Nasional. Jakarta: CV. Haji Masagung.

Wei-jie Guan, Z.-y. N., Yu Hu, , Wen-hua Liang, Chun-quan Ou, et. al. (2020). Clinical Characteristics of Coronavirus Disease 2019 in China. The New England Journal of Medicine, 382, 1708-1720.

Kalla, Y., Jamal, M., Budiman. (2018). Partisipasi Masyarakat dalam Pembangunan Fisik di Kelurahan Gunung Kelud Kecamatan Samarinda ULU. eJournal Ilmu Pemerintahan, 6 (4), 1689-1702. 